\title{
Assessment of the level of knowledge of patients from selected Warsaw hospitals about Crohn's disease
}

\author{
Karolina Turek ${ }^{1}$ Joanna Gotlib² \\ ${ }^{1}$ Faculty of Health Science, Medical University of Warsaw, Poland \\ Head of the Faculty: Prof. Piotr Małkowski \\ ${ }^{2}$ Division of Teaching and Outcomes of Education, Faculty of Health Science, Medical University of Warsaw, Poland \\ Head of the Division: Joanna Gotlib MD, PhD
}

Studia Medyczne 2013; 29 (3): 219-224

Key words: inflammatory bowel disease, intestinal diseases, Crohn's disease, knowledge, patients.

\begin{abstract}
Introduction: Crohn's disease constitutes one of the most serious diagnostic-therapeutic problems of contemporary gastroenterology and appropriate lifestyle may prevent symptoms of this disease.

Aim of the research: To assess the level of patient knowledge of Crohn's disease.

Material and methods: The study enrolled 100 patients from three Warsaw hospitals (53 women). Mean age of the study population was 34.6 years (min. 18 , max. 60 ; $\mathrm{SD}=5.690$ ). The voluntary and anonymous questionnaire study used a questionnaire developed by the authors (32 questions). Statistical analysis of the study results was carried out in the StatSoft Statistica 10.0 program, using the Mann-Whitney $U$ test. The significance level was established at $p<0.05$.

Results: The study group of patients had basic knowledge of Crohn's disease. A majority of the study participants (over 60\%) knew the key factors responsible for the development of non-specific inflammatory bowel disease, $64 \%$ of them knew the effects of immunosuppressive therapy, and $77 \%$ of the patients correctly indicated the group of drugs used in the therapy; however, detailed knowledge of the disease significant for further treatment and its influence on the quality of life was insufficient and required supplementation. Differences among women and men were statistically insignificant $(p=\mathrm{NS})$.

Conclusions: Studies on patient knowledge of Crohn's disease are rarely published in Polish and world scientific literature and therefore there is a need for continuation of studies. Detailed knowledge of patients about Crohn's disease was insufficient. Therefore, information campaigns and actions as well as continuous education of patients performed by members of interdisciplinary therapeutic teams are justified. The level of knowledge of Crohn's disease is not gender-related. The study results may be used in practice for development of educational programmes for patients with this disease.
\end{abstract}

\section{Introduction}

Crohn's disease is one of the most serious diagnostic-therapeutic problems of contemporary gastroenterology [1-4]. The first case of the disease was described in 1903 by Antoni Leśniowski, who presented a bowel biopsy of a female patient showing the ileo-caecal region that had been removed due to obstruction and numerous ulcerations [1]. Studies conducted so far have not indicated a direct cause of the disease [1-11].

The incidence of non-specific inflammatory bowel disease has rapidly increased in recent years [12-20]. Due to the fact that Crohn's disease mostly affects young patients (aged 18-40) who would like to be professionally active, the issue of disease management has gained interest [12-20]. A correct diagnosis and proper treatment improve the quality of life, and the maintenance of a proper lifestyle (e.g. proper dietary management) constitutes one of the most important factors influencing the patient's condition [12-20]. Therefore, providing patients with Crohn's disease with proper information and education on maintaining a proper lifestyle that may prevent symptoms of this disease is of such importance $[12,13,15,16,18-22]$.

A Polish, authorized website http://www.chorobacrohna.pl was established only several years ago and contains data on the disease that are crucial for both patients and doctors [23]. The website also presents an up-to-date review of the literature and the National Register of Crohn's Disease. However, it needs to be remembered that these sources are not always comprehensible for patients.

The available Polish and world literature (Polish Medical Bibliography, PubMed, EMBASE, SCOPUS) presents a number of publications on various clinical issues concerning the essence of Crohn's disease [2-7], 9-12]. However, only a few publications deal with patient knowledge of this disease [18-20]. The present study provides an innovative depiction of the problem. The present results may be used in practice in order to define the areas of insufficient knowledge of patients about their disease and to develop education programmes for patients with Crohn's disease on the basis of the present results. 


\section{Aim of the research}

The main aim of the study was to assess the level of patient knowledge of Crohn's disease. A detailed aim of the study was to compare the level of knowledge of the disease between females and males.

\section{Material and methods}

The study enrolled a group of 100 patients: 53 women (group 1) and 47 men (group 2) with Crohn's disease. These were consecutive patients who presented to the following three Warsaw hospitals: Hospital of the Ministry of Interior, Maria Skłodowska-Curie Institute of Oncology, and Professor Witold Orłowski Independent Public Clinical Hospital - Postgraduate Medical Education Centre. Such a selection method was an assurance of randomisation.

The selection of patients was conducted according to the following criteria:

- having this particular disease,

- providing oral, informed consent of the participant

- before the study, a surveyor provided patients with detailed information on the aim, range, and method of the study,

- no history of known mental disease.

Mean age of the study population was 34.6 years (min. 18, max. 60; SD = 5.690). Patients with a higher education degree comprised a majority of the study group (51 persons), patients with a secondary school degree accounted for $40 \%$ of the total, and patients with a vocational education degree represented $9 \%$. The largest group of the study participants (36\%) lived in a town with a population over 500,000 people, $30 \%$ of the total lived in a town with a population between 20,000 and 100,000 people, and the smallest number of the study participants $(16 \%)$ lived in towns with a population below 20,000. As many as $18 \%$ of the patients lived in the country. A diagnostic poll method with a survey technique was used in the study. The voluntary, anonymous questionnaire study was conducted between December, 2011 and March, 2012. The questionnaire developed by the authors was given to each patient personally by a surveyor. The questionnaire comprised 32 questions, including 30 closed-ended questions.

\section{Statistical analysis}

The data were collected in the Microsoft Excel program. The StatSoft Statistica 10.0 program (licensed to Warsaw Medical University) was used for statistical analysis of the results. Owing to the fact that two separate groups of patients - women (group 1) and men (group 2) - were compared and due to the nature of the data (qualitative, non-parametric data) and the absence of normal distribution of the data (ShapiroWilk test: $p>0.05$ ), the non-parametric Mann-Whitney $U$ test was used for the statistical analysis. The significance level was established at $p<0.05$.

\section{Results}

The study group had a basic knowledge of Crohn's disease. However, the knowledge of detailed information crucial for the efficiency of further therapy and its influence on the quality of life was insufficient. The majority of the study participants knew the key factors responsible for the development of non-specific inflammatory bowel disease. Differences among women and men were statistically insignificant ( $p=\mathrm{NS}$ ). See Table 1 for detailed data.

The other part of the questionnaire concerned the knowledge of the patients about possibilities of pharmacological treatment of Crohn's disease. More than half of the study participants (64\%) knew the effects of immunosuppressive therapy and a vast majority of the total (77\%) correctly indicated the group of drugs used in the therapy (Table 2). Differences among women and men were statistically insignificant ( $p=\mathrm{NS})$.

\section{Discussion}

A vast majority of the available Polish and world publications relate to an assessment of the quality of life of patients with non-specific inflammatory bowel disease [19-21, 24-30]. A significantly smaller number of publications are devoted to an analysis of the level of patient knowledge of Crohn's disease [18-20].

The results of the Crohn's and Colitis Knowledge Score (CCKNOW) test that assessed the level of knowledge of non-specific inflammatory bowel diseases (including mostly Crohn's disease and ulcerative colitis) is one of not numerous world publications referring to measurement of knowledge of Crohn's disease [18].

The study was conducted in a British hospital. Initially, it enrolled physicians, nurses, and administration staff. As predicted, the level of knowledge of the physicians was higher than that of the nurses, and their level of knowledge was higher than that of the hospital administration staff. Seeking test reliability and legibility, the test was modified on an ongoing basis and, after being used with reference to the specified groups of employees, it became a tool to measure the level of knowledge of the target group, i.e. patients with Crohn's disease and ulcerative colitis [18].

The questionnaire study conducted among patients of Leicestershire county included the following areas: general knowledge of the disease, anatomy, complications, diet, and treatment. A vast majority of the study participants (96\%) knew that it is not a direct contact spread disease, but as many as $72 \%$ of the patients were not aware that it is a familial disease, and almost half of the study group did not know that it may affect other organs as well, not only the intestines. Most of the patients knew that they have not fully recovered even if the symptoms have not occurred for 3 years [18]. 
Table 1. Patients' knowledge of Crohn's disease

\begin{tabular}{|c|c|c|c|c|c|c|}
\hline $\begin{array}{l}\text { Item } \\
\text { no. }\end{array}$ & & Question & 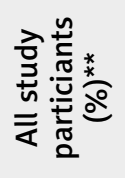 & 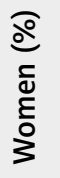 & 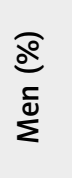 & $\begin{array}{l}\frac{2}{0} \\
\frac{0}{2} \\
\frac{0}{5} \\
>\end{array}$ \\
\hline 1 & $\begin{array}{l}\text { What are the } \\
\text { most common sites of } \\
\text { Crohn's disease?* }\end{array}$ & $\begin{array}{l}\text { Small intestine } \\
\text { Caecum } \\
\text { Rectum } \\
\text { lleum and colon } \\
\text { Colon } \\
\text { The entire large intestine } \\
\text { Do not know }\end{array}$ & $\begin{array}{l}70 \\
28 \\
20 \\
44 \\
1 \\
42 \\
3\end{array}$ & $\begin{array}{l}39 \\
15 \\
10 \\
22 \\
0 \\
22 \\
3\end{array}$ & $\begin{array}{c}31 \\
13 \\
10 \\
22 \\
1 \\
20 \\
0\end{array}$ & 0.671 \\
\hline 2 & $\begin{array}{l}\text { Which factors influence } \\
\text { the development of non- } \\
\text { specific inflammatory } \\
\text { bowel disease?* }\end{array}$ & $\begin{array}{l}\text { Environmental factors } \\
\text { Genetic conditioning } \\
\text { Bacterial flora of the digestive tract } \\
\text { Unhealthy dietary patterns } \\
\text { Abnormalities in the intestinal immunological } \\
\text { system } \\
\text { Do not know }\end{array}$ & $\begin{array}{l}64 \\
71 \\
36 \\
28 \\
76 \\
6\end{array}$ & $\begin{array}{l}32 \\
41 \\
18 \\
13 \\
43 \\
3\end{array}$ & $\begin{array}{l}32 \\
30 \\
18 \\
15 \\
33 \\
3\end{array}$ & 0.789 \\
\hline 3 & $\begin{array}{l}\text { Which symptoms are } \\
\text { characteristic } \\
\text { of Crohn's disease?* }\end{array}$ & $\begin{array}{l}\text { Pain in the right hypogastrium } \\
\text { Weight loss } \\
\text { Fatigue, weakness, loss of appetite } \\
\text { Fever } \\
\text { Increase in bowel movement frequency with } \\
\text { bloody and mucous stools } \\
\text { Persistent bloody diarrhoea } \\
\text { Abdominal pain } \\
\text { Headache } \\
\text { Changes in the anal area } \\
\text { Do not know }\end{array}$ & $\begin{array}{c}51 \\
91 \\
71 \\
54 \\
80 \\
\\
41 \\
78 \\
9 \\
37 \\
2\end{array}$ & $\begin{array}{c}32 \\
49 \\
38 \\
31 \\
42 \\
\\
23 \\
43 \\
6 \\
23 \\
1\end{array}$ & $\begin{array}{c}19 \\
42 \\
33 \\
23 \\
38 \\
18 \\
35 \\
3 \\
14 \\
1\end{array}$ & 0.901 \\
\hline 4 & Fistula is: & $\begin{array}{l}\text { An abnormal connection between two organs } \\
\text { (mostly intestines) or between an organ and } \\
\text { the skin } \\
\text { A narrowing in the intestines that causes an } \\
\text { obstruction to the flow of chyme } \\
\text { lleorectostomy } \\
\text { An abnormal hole in the intestinal wall that } \\
\text { joins it to the peritoneal cavity } \\
\text { Do not know }\end{array}$ & $\begin{array}{c}8 \\
1 \\
22 \\
14\end{array}$ & $\begin{array}{c}7 \\
1 \\
11 \\
8\end{array}$ & $\begin{array}{c}1 \\
0 \\
11 \\
6\end{array}$ & 0.602 \\
\hline 5 & $\begin{array}{l}\text { Which examinations are } \\
\text { performed in cases with } \\
\text { suspicion of non-specific } \\
\text { inflammatory bowel } \\
\text { disease?* }\end{array}$ & $\begin{array}{l}\text { Blood studies } \\
\text { Abdominal ultrasound } \\
\text { Colonoscopy } \\
\text { Radiograph of the large intestine } \\
\text { Gastroscopy } \\
\text { Endoscopic ultrasound - fistula examination } \\
\text { Computed tomography (CT) } \\
\text { Magnetic resonance imaging (MRI) }\end{array}$ & $\begin{array}{l}78 \\
69 \\
96 \\
29 \\
67 \\
21 \\
55 \\
30\end{array}$ & $\begin{array}{l}43 \\
37 \\
51 \\
13 \\
35 \\
15 \\
30 \\
20\end{array}$ & $\begin{array}{l}35 \\
32 \\
45 \\
16 \\
32 \\
6 \\
25 \\
10\end{array}$ & 0.703 \\
\hline 6 & $\begin{array}{l}\text { Which age range experiences } \\
\text { the highest rate of incidence? }\end{array}$ & $\begin{array}{l}\text { Between } 40 \text { and } 49 \text { years of age } \\
\text { Between } 16 \text { and } 39 \text { years of age } \\
\text { Between } 50 \text { and } 59 \text { years of age } \\
\text { Over } 60 \text { years of age } \\
\text { Do not know }\end{array}$ & $\begin{array}{l}6 \\
81 \\
- \\
- \\
13\end{array}$ & $\begin{array}{l}4 \\
41 \\
- \\
- \\
8\end{array}$ & $\begin{array}{c}2 \\
40 \\
- \\
- \\
3\end{array}$ & 0.665 \\
\hline 7 & $\begin{array}{l}\text { If no symptoms occur } \\
\text { within } 3 \text { years, patients with } \\
\text { non-specific inflammatory } \\
\text { bowel disease have possibly } \\
\text { recovered. }\end{array}$ & $\begin{array}{l}\text { True } \\
\text { False } \\
\text { Do not know }\end{array}$ & $\begin{array}{c}5 \\
79 \\
16\end{array}$ & $\begin{array}{c}2 \\
40 \\
11\end{array}$ & $\begin{array}{c}3 \\
39 \\
5\end{array}$ & 0.893 \\
\hline
\end{tabular}


Table 1. cont.

\begin{tabular}{|c|c|c|c|c|c|c|}
\hline $\begin{array}{l}\text { Item } \\
\text { no. }\end{array}$ & & Question & 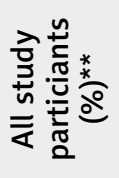 & $\begin{array}{l}\text { ঐ } \\
\text { ఏ } \\
\text { ह } \\
\vdots\end{array}$ & $\underset{\sum}{\stackrel{c}{d}}$ & $\begin{array}{l}2 \\
\frac{0}{0} \\
\frac{0}{3} \\
\frac{\pi}{5}\end{array}$ \\
\hline 8 & $\begin{array}{l}\text { Drawing the small or large } \\
\text { intestine through the abdominal } \\
\text { wall is called: }\end{array}$ & $\begin{array}{l}\text { Pouch } \\
\text { Anastomosis } \\
\text { Stoma (colostomy/ileostomy) } \\
\text { Do not know }\end{array}$ & $\begin{array}{c}2 \\
2 \\
88 \\
8\end{array}$ & $\begin{array}{c}0 \\
1 \\
48 \\
4\end{array}$ & $\begin{array}{c}2 \\
1 \\
40 \\
4\end{array}$ & 0.934 \\
\hline 9 & $\begin{array}{l}\text { Persons with non-specific } \\
\text { inflammatory bowel disease do } \\
\text { not consume dairy products: }\end{array}$ & $\begin{array}{l}\text { True } \\
\text { False } \\
\text { Do not know }\end{array}$ & $\begin{array}{c}20 \\
73 \\
7\end{array}$ & $\begin{array}{c}9 \\
39 \\
5\end{array}$ & $\begin{array}{c}11 \\
34 \\
2\end{array}$ & 0.653 \\
\hline 10 & $\begin{array}{l}\text { Does smoking influence Crohn's } \\
\text { disease? }\end{array}$ & $\begin{array}{l}\text { Yes } \\
\text { No } \\
\text { Do not know }\end{array}$ & $\begin{array}{l}75 \\
10 \\
15\end{array}$ & $\begin{array}{l}41 \\
5 \\
7\end{array}$ & $\begin{array}{c}34 \\
5 \\
8\end{array}$ & 0.481 \\
\hline
\end{tabular}

$p$-significance level, *more than one answer could be provided, ${ }^{*}$ the number of study participants was 100, so the proportion of study participants is equal to the number of patients

Table 2. Patient knowledge of medications used in Crohn's disease

\begin{tabular}{|c|c|c|c|c|c|c|}
\hline $\begin{array}{c}\text { Item } \\
\text { no. }\end{array}$ & & Question & 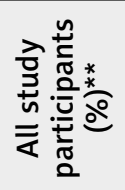 & 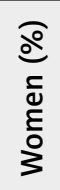 & $\begin{array}{l}\text { @ } \\
\frac{c}{2}\end{array}$ & $\begin{array}{l}2 \\
\frac{2}{0} \\
\frac{1}{5} \\
\frac{1}{3}\end{array}$ \\
\hline 1 & $\begin{array}{l}\text { Glucocorticoids, such as } \\
\text { prednisone, budesonide, } \\
\text { hydrocortisone: }^{*}\end{array}$ & $\begin{array}{l}\text { Can be administered as rectal infusion } \\
\text { Can be administered orally } \\
\text { Can be administered directly to a vein } \\
\text { Do not know }\end{array}$ & $\begin{array}{l}29 \\
58 \\
47 \\
23\end{array}$ & $\begin{array}{l}18 \\
28 \\
21 \\
12\end{array}$ & $\begin{array}{l}11 \\
30 \\
26 \\
11\end{array}$ & 0.893 \\
\hline 2 & $\begin{array}{l}\text { Steroids usually produce } \\
\text { side-effects: }\end{array}$ & $\begin{array}{l}\text { When taken for a long period in high doses } \\
\text { When taken in small doses and for a short period } \\
\text { When doses are not fixed and side-effects resolve } \\
\text { with the end of the therapy } \\
\text { Do not know }\end{array}$ & $\begin{array}{c}66 \\
6 \\
12 \\
17\end{array}$ & $\begin{array}{l}35 \\
5 \\
5 \\
8\end{array}$ & $\begin{array}{c}31 \\
1 \\
7\end{array}$ & 0.777 \\
\hline 3 & Sulfasalazine: & $\begin{array}{l}\text { Monitors the levels of sulfur in the body } \\
\text { Is used to decrease the incidence of exacerbation } \\
\text { of the disease } \\
\text { Cannot be used in exacerbation of the disease } \\
\text { Do not know }\end{array}$ & $\begin{array}{c}2 \\
75 \\
1 \\
24\end{array}$ & $\begin{array}{c}1 \\
38 \\
0 \\
14\end{array}$ & $\begin{array}{c}1 \\
37 \\
1 \\
10\end{array}$ & 0.259 \\
\hline 4 & $\begin{array}{l}\text { Immunosuppressive } \\
\text { drugs used in Crohn's } \\
\text { disease include the } \\
\text { following: }\end{array}$ & $\begin{array}{l}\text { Mesalazine } \\
\text { Sulfasalazine } \\
\text { Azathioprine } \\
\text { Do not know }\end{array}$ & $\begin{array}{c}13 \\
14 \\
77 \\
9\end{array}$ & $\begin{array}{l}10 \\
10 \\
37 \\
4\end{array}$ & $\begin{array}{c}3 \\
4 \\
40 \\
5\end{array}$ & 0.721 \\
\hline 5 & Immunosuppression: & $\begin{array}{l}\text { Prevents bacterial infections of the intestines } \\
\text { Reduces the inflammation levels in the intestines } \\
\text { Prevents viral infections } \\
\text { Is the only alternative to surgical treatment } \\
\text { Do not know }\end{array}$ & $\begin{array}{c}4 \\
64 \\
4 \\
8 \\
23\end{array}$ & $\begin{array}{c}4 \\
33 \\
2 \\
3 \\
12\end{array}$ & $\begin{array}{c}0 \\
31 \\
2 \\
5 \\
11\end{array}$ & 0.489 \\
\hline
\end{tabular}

$p$-significance level, *more than one answer could be provided, ${ }^{* *}$ the number of study participants was 100, so the proportion of study participants is equal to the number of patients

Similarly, the study by Perek and Cepuch showed that the youth with Crohn's disease knew that both this disease and ulcerative colitis are clinically incurable and chronic, with periods of remission and exac- erbation. However, to the question about the causes of non-specific inflammatory bowel disease, the young patients answered that they are not fully recognised. As few as 19\% of the study participants indicated ge- 
netic load as a cause of the disease [19]. In the present study, approximately $70 \%$ of the patients correctly indicated the three key factors: environmental, genetic, and abnormalities in the intestinal immunological system.

Better knowledge of aetiology of the disease among this group may result from a greater health awareness of patients in the productive age. Nevertheless, a low level of knowledge among the English patients about the influence of family correlations on the development of the disease is surprising [19]. Similarly, the study by Hawkey and Hawkey demonstrated a lack of knowledge of the familial incidence of inflammatory bowel disease [20].

A detailed analysis of the level of knowledge among this group needs to be supplemented with the level of knowledge of drugs administered to the British patients with Crohn's disease. More than half of the study group (60\%) understood the effects of immunosuppressive drugs, but $76 \%$ of the total thought that sulfasalazine and mesalazine are examples of such medicines [18]. Better results were obtained with patients from Warsaw hospitals: $77 \%$ of the study participants correctly indicated azathioprine as an example of such a drug. Similarly, in the study by Perek and Cepuch the youth managed to list names of the drugs and half of the study participants were able to specify their activity [19]. The respondents from Warsaw hospitals demonstrated a similar knowledge, showing a wide knowledge of routes of administration of the so-called glucocorticoids, whereas half of the Leicestershire respondents did not know that these drugs can be administered per rectum, intravenously, and orally [18].

The study by Perek and Cepuch show the level of health awareness of patients with Crohn's disease. Most of the study participants knew that the use of stimulants may affect the course of the disease, but $21.9 \%$ of the respondents reported that smoking has no effect on the development of the disease [19]. In the present study, a majority of the participants reported that tobacco exerts a negative effect on the course of Crohn's disease. Surprising results were obtained among the British patients: as many as $77 \%$ of them were not aware of the fact that smoking may significantly affect the development of the disease and lead to its exacerbation [18]. The lack of knowledge in this area may be a result of insufficient education of patients or their ignorance regarding the influence of harmful substances on the disease process. Nevertheless, it is worth emphasising that the expenditures on health protection and education in the UK are among the highest in the entire European Union.

The present results demonstrate the need to continue studies on the patient knowledge of non-specific inflammatory bowel diseases. More detailed studies should focus on the assessment of behaviour of patients and their compliance with instructions with reference to the outcomes of treatment.

\section{Conclusions}

An analysis of the available literature demonstrates that studies on the patient knowledge of Crohn's disease are not common and are rarely published in Polish and world scientific literature; therefore there is a need for continuation of studies. Among the study group, detailed knowledge of Crohn's disease was insufficient. Therefore, information campaigns and actions as well as continuous education of patients performed by members of interdisciplinary therapeutic teams are justified. Among the study group, the level of knowledge of Crohn's disease was not gender-related. The study results could be used in practice for development of educational programmes devoted to Crohn's disease for patients with this disease.

\section{References}

1. Bartnik W. Wytyczne postępowania w nieswoistych chorobach zapalnych jelit. Prz Gastroenterol 2007; 2: 215-229.

2. Kosiarska M, Łapińska J, Siemianów-Wejchert J. Objawy pozajelitowe nieswoistych zapaleń jelit. Gastroenterol Pol 2009; 16: 475-480.

3. Wyszykowski M, Rydzewska G. Nadzór endoskopowy w nieswoistych chorobach zapalnych jelit. Prz Gastroenterol 2011; 6: 279-283.

4. Kosiara M, Łapińska J, Siamianów-Wejchert J. Objawy pozajelitowe nieswoistych zapaleń jelit. Gastroenterol Pol 2009; 16: 475-480.

5. Paradowska A. Oral mucosa at Crohn's disease. Gastroenterol Pol 2009; 15: 309-311.

6. Radwan P, Radwan-Kwiatek K, Skrzydło-Radomańska B. Niedokrwistość w nieswoistych zapaleniach jelit - etiopatogeneza, rozpoznawanie i leczenie. Prz Gastroenterol 2010; 5: 315-320.

7. Neubauer K, Paradowski L. Leczenie podtrzymujące remisję w nieswoistych zapaleniach jelit. Gastroenterol Pol 2010; 17: 129-132.

8. Paradowski L, Neubauer K, Reszczyńska M. Zmiany w konsensusie ECCO 2010 dotyczącym postępowania w chorobie Leśniowskiego-Crohna. Gastroenterol Pol 2010; 17: 123-126.

9. Kargulewicz A, Stankowiak-Kulpa H. Rola leczenia żywieniowego w chorobie Leśniowskiego-Crohna. Gastroenterol Pol 2010; 4: 234-245.

10. Domżał-Magrowska D, Talar-Wojnarowska R, Kotynia J. Skuteczność i bezpieczeństwo terapii biologicznej w przebiegu choroby Leśniowskiego-Crohna - doświadczenia własne. Prz Gastroenterol 2011; 6: 304-309.

11. Bednarz W, Olewiński R, Głód M. Surgical treatment of Crohn's disease. Gastroenterol Pol 2010; 17: 261-266.

12. Froch B, Zwolińska-Wcisło M, Bętkowska-Korpała B. Dynamika reakcji emocjonalnych $u$ chorych na nieswoiste zapalenia jelit. Prz Gastroenterol 2009; 4: 141-146.

13. Lickiewicz B, Zwolińska-Wcisło M, Lickiewicz J. Znaczenie cech osobowości $w$ procesie adaptacji do choroby u pacjentów z nieswoistymi zapaleniami jelit. Prz Gastroenterol 2010; 5: 157-163.

14. Radwan P, Radwan-Kwiatek K, Kwiatek M. Wpływ nieswoistych zapaleń jelit na płodność oraz przebieg ciąży i porodu. Prz Gastroenterol 2008; 3: 295-301. 
15. Baczewska-Mazurkiewicz D, Rydzewska G. Problemy żywieniowe pacjentów z nieswoistymi chorobami zapalnymi jelit. Prz Gastroenterol 2011; 6: 69-77.

16. Prescha A, Pieczyńska J, Biernat K. Nutritional status assessment of patients with inflammatory bowel disease. Gastroenterol Pol 2010; 17: 25-31.

17. Banasiewicz T, Borycka-Kiciak K, Dobrowolska-Zachwieja A. Kliniczne aspekty zastosowania kwasu masłowego w postępowaniu dietetycznym w chorobach jelit. Prz Gastroenterol 2010; 5: 329-334.

18. Eaden JA, Abrams K, Mayberry JF. The Crohn and Colitis Knowledge Score: test for measuring patient knowledge in inflammatory bowel disease. Am J Gastroenterol 1999; 94: 3560-3566.

19. Perek M, Cepuch G. Poziom wiedzy i jakość życia młodzieży chorej na nieswoiste zapalenia jelit. Pielęgniarstwo XXI wieku 2011; 2: 130-137.

20. Hawkey GM, Hawkey CJ. Effect of information leaflets on knowledge in patients with inflammatory bowel disease. Gut 1989; 30: 1641-1646.

21. Andrzejewska J, Talarska T, Michalak M. Quality of life in patients with Crohn's disease and ulcerative colitis. Comparative analysis. Prz Gastroenterol 2009; 4: 251-255.

22. Jakubowska-Burek J, Warmuz-Stangierska I, Kaczmarek E. Quality of life estimation by Polish and American inflammatory bowel disease patients - pilot study. Prz Gastroenterol 2011; 6: 388-400.

23. Wiercińska-Drapało A, Jaroszewicz J, Flisiak R. Epidemiological characteristics of inflammatory bowel disease in North-Eastern Poland. World J Gastroenterol 2005; 11: 2630-2633.

24. Andrzejewska J, Talarska T. Jakość życia w nieswoistych zapaleniach jelit. Analiza i walidacja nowego narzędzia badawczego. Prz Gastroenterol 2009; 4: 88-92.

25. Mittermaier C, Dejaco C, Waldhoer T. Impact of depressive mood on relapse in patients with inflammatory bowel disease: a prospective 18-month follow-up study. Psychosom Med 2004; 66: 79-84.

26. Heinrich G, Hersbach P. Question on life satisfaction (FLZM) - a short questionnaire for assessing subjective quality of life. Eur J Psychol Assess 2000; 16: 150-159.

27. Russel M, Boclar U, Nagrl N. Pedictors of disease- related concers and other aspect of HRQL in outpatients with inflammatory bowel disease. Eur J Gastroenterol Hepatol 2004; 16: 1273-1280.

28. Marcus SB, Strople JA, Neighbors K. Fatique and healthrelated quality of life in pedaiatric inflammatory bowel disease. Clin Gastroenterol Heaptol 2009; 7: 554-561.

29. Drossman DA, Leserman J, Li. Z. The rating form of IBD patient concerns: a new measure of health status. Psychosom Med 1991; 53: 701-712.

30. Belling R, McLaren S, Woods L. Specialist nursing for inflammatory bowel disease (Review). The Cochrane Library 2009/4. John Wiley and Sons Ltd. 2009.

\section{Address for correspondence:}

Joanna Gotlib

Division of Teaching and Outcomes of Education

Faculty of Health Science

Medical University of Warsaw

ul. Żwirki i Wigury 61, 02-091 Warsaw, Poland

Phone: +48 225720490

Fax: +48225720491

E-mail: joanna.gotlib@wum.edu.pl 